\title{
The Maintenance of Peace in Mozambique: From GPA to the First Multiparty Elections, 1992-1994
}

\author{
Rufino Carlos Gujamo \\ Joaquim Chissano University, Maputo, Mozambique
}

\begin{abstract}
After sixteen years of civil war the Mozambican government led by the Mozambique Liberation Front (FRELIMO) and the Mozambican National Resistance (RENAMO) have signed the General Peace Agreement (GPA) in Rome, Italy, on 4th October 1992. The agreement that ended the war resulted from a negotiation process initiated following the hurting stalemate situation between the two conflicting parties. In the context of the implementation of such agreement the country experienced, successfully, the first multiparty elections in 1994 with the participation of FRELIMO and RENAMO - former military enemies as well as other political parties without any case of war resumption. This article seeks to identify the determinants factors for peace maintenance in Mozambique from the General Peace Agreement (GPA) to the first multiparty elections. Besides the important support provided by the international community, this article argues that the implementation of power sharing arrangements established in the context of GPA, namely, (1) military power sharing, (2) administrative and territorial power sharing, and (3) power sharing within the electoral institutions played an important role for peace maintenance in Mozambique during the period mentioned above.
\end{abstract}

Keywords: peace maintenance, power sharing, military power sharing, administrative and territorial power sharing, power sharing within the electoral institutions

The period immediately following the proclamation of independence in Mozambique was marked by the outbreak of a devastating civil war opposing the Mozambican National Resistance (RENAMO) to the government forces led by the Liberation Front of Mozambique (FRELIMO). The 16 year's conflict (civil war) resulted from the combination of external and internal factors. External factors include the Cold War, Southern Rhodesia and South Africa's interest in destabilizing Mozambique due to the latter's support to the Zimbabwe African National Union (ZANU) and the African National Congress (ANC). The two nationalist movements fought against white minority regimes in Rhodesia and South Africa, respectively (Honwana, 1995; Weinstein \& Francisco, 2005). Mozambique's support to ZANU and the ANC represented a threat to the safety of the allied white minority regimes. Besides the external factors, the literature highlights internal causes for Mozambican civil war such as the implementation of the single party regime by FRELIMO; the FRELIMO's government hostilities against religions and traditional authorities, the creation of communal villages, and the abandonment of participatory democracy that had been characteristic in liberated areas during the armed struggle for independence.

On 4 October 1992, the main conflicting parties, namely the Mozambican government led by FRELIMO

Rufino Carlos Gujamo, Ph.D., Lecturer, Joaquim Chissano University, Maputo, Mozambique. 
and RENAMO, signed the General Peace Agreement (GPA), ending the civil war which caused about one million peoples death, one million and seven hundred thousand refugees abroad, four million internally displaced people, deep social fractures and the destruction of economic and social infrastructure in the country.

As part of the GPA implementation, the first multi-party elections (legislative and presidential elections) were held in 1994. The electoral results were respected by citizens and political parties throughout the country, including RENAMO despite some complaints presented by this political organization. However, after the elections, RENAMO did not submit any complaint to the International Electoral Tribunal (Vieira, 2010, p. 724). RENAMO elected members took office in the Parliament, a gesture that represented the recognition of the electoral results. This article seeks to analyze and understand what has contributed for the positive engagement of FRELIMO's government and RENAMO in the implementation of GPA from 1992 to 1994, preserving peace and democracy besides the continuing interest contradiction between the two former conflicting parties.

Two approaches dominate the studies on the peaceful resolution of conflicts. The first stresses that the success of the process of building a negotiated solution for the conflict lies primarily in the nature and content of the agreements reached between the conflicting parties (Rosemary \& Hoddie, 2007; Rothchild, 1997). The second approach emphasizes that the construction of a negotiated solution for a conflict and its success depends on the chosen time for the completion of the resolution efforts. This approach quite predominant in the conceptual and theoretical literature on conflict resolution has William Zartaman as main reference among other authors (Zartman, 2000; 2001; Pruitt, 2007; Yusuf \& Najam, 2009; Kleiboer, 1994; Spector, 2002).

Although the nature and content of the agreements are clearly important for the construction and maintenance of peace, the first approach referred above does not help to understand the reasons that determine the engagement of opposing parties in search for a solution based on the process of bilateral or multilateral cooperation at the expense of unilateral solutions dominant in the whole period of conflict escalation. It is in this context that the second approach based on the chosen time for the resolution of the conflict assumes a high relevance. In the context of this approach, the conflict ripeness is important to explain the initiation of negotiations, indicating the necessary conditions, though not sufficient for it (Zartman, 2000, p. 226).

According to William Zartman, ripeness is the moment in which the conflicting parties realize that they are in a situation of stalemate, mutually painful, associated with an impending catastrophe, past or recently avoided. The concept is based on the idea that when the contenders are in a situation of locked conflict and none of them can reach their goals satisfactorily through unilateral actions and such blockade is painful, the parties in conflict decide to search for a negotiated solution as the best alternative (Zartman, 2000, p. 228). Therefore, according to the author, the parties resolve peacefully the conflict only when they are prepared to do so. When the use of unilateral means to reach satisfactory goals is blocked, therefore the conflicting parties are confronted with an uncomfortable situation (Zartman, 2001, p. 8). In this situation, the conflicting parties decide to explore the negotiation alternatives which for a long time have been discarded. In this context, according to William Zartman, the ripeness has two components, namely the perception of mutually painful stalemate between the two parties, on the one hand, and on the other, the perception of the possibility of a negotiating output (Zartman, 2000, pp. 225-228). The external parties (third parties) of the conflict can influence the primary parts in order to realize the tie mutually painful or the time of conflict ripeness, encouraging them to engage in a negotiated solution (Schrodt, Yilmaz, \& Gerner, 2003; Achankeng I, 2012).

However, not all situations of conflict ripeness lead to peace negotiations or to the resolution of the conflict (Yusuf \& Najam, 2009; Zartman, 2000). According to William Zartman there are situations in which the hurting 
stalemate leads to the exacerbation of the conflict. These situations result from communication problems between the conflicting parties. Such problems may result from stereotyped visions among the contenders, hatred feelings of injustice, desire for revenge and other factors (Pruitt, 2005, p. 3).

Ripeness as an important condition for the beginning of negotiations or mediation and its success has been advocated by many authors. Based on ripeness theory, Michael Greig argues that the success of negotiation and mediation depends on five fundamental factors, namely: (i) The existence of high costs and the suffering resulting from a long period of rivalries increases the possibility of mediation to improve the relationship between the parties in conflict; (ii) the perception among the rivals on its inability to unilaterally amend the level of rivalry in their favor contributes to the engagement in cooperation initiatives; (iii) the level of perceived threat by rivals has influence on its openness to international mediation efforts; (iv) the internal political changes may contribute to the strengthening of the possibility of the mediation and help to improve relations between the parties; and (v) the belief among the warring parties about the existence of a basis for an agreement can contribute for the success of the mediation efforts (Greig, 2001, p. 693). The author emphasizes that the mediation driven in the initial phase of the conflict is unlikely to be successful once the parties in dispute still believe that they can achieve their goals by unilateral track. Thus Greig highlights that mediation is more likely to be successful when it happens at a late stage of conflict when the parties perceive the mutual hurting stalemate.

Analyzing the Mozambican case, André Thomashausen underlines that in 1988 the civil war has reached the situation of a mutually hurting stalemate. This fact contributed to the involvement of the conflicting parties in search for a negotiated solution for the dispute (Thomashausen, 2001, p. 104). Also, Ricardo Sousa, analyzing the case of Angola, particularly the Gbadolite and New York peace agreements concluded that the conflict ripeness has played an important role in the opening of the parties to the efforts for a negotiated solution to end civil war (Sousa, 2012).

However, Marieke Kleiboer argues that ripeness is a concept which refers to the will of the parties, factions, and its leaders. Thus, Kleiboer concludes that ripeness corresponds to the moment in which all parties have desire to search for a peaceful solution (agreement) (Kleiboer, 1994, p. 115). In this way the author emphasizes that the will is the minimum requirement for a negotiated solution. In the same perspective, Steven Forde defines ripeness as the moment in which the parties in conflict are available to accept a negotiated solution (Forde, 2004). The approaches of Kleiboer and Forde suggest that the hurting stalemate does not necessarily correspond to the conflict ripeness. According to the conceptual approach of these authors the mutually hurting stalemate should be understood as one of the factors driving to ripeness defined as the willingness of the conflicting parties to begin the negotiations.

Thus, analyzing the factors determining the end of civil war in Rhodesia, Matthew Preston concluded that although there has been a situation of military parity or mutually hurting stalemate between the guerrilla movement and the Rhodesian security forces, the political factors and especially the external pressure from Mozambique, South Africa, and Zambia, the deterioration of relations between the military and the civilians, and the competition for leadership within the warring factions have influenced the parties to choose a negotiated settlement for the conflict (Preston, 2004). Although the author recognizes the absence of mutually hurting stalemate as a determining factor for the beginning of negotiations between the parties, simultaneously, he stresses the role of external actors in creating the perception of the parties about the favorable opportunity to start negotiations. Therefore, Matthew Preston strengthens the implicit argument in Kleiboer and Forde's approach according to which the mutually hurting stalemate among other factors contributes for conflict ripeness. 
Dean Pruitt suggested the readiness theory. According to Pruitt the theory of readiness differs from ripeness theory. The first theory is based on the psychology of the leadership from each conflicting part and on its thought, while the second theory is centered on the thought of the two conflicting parties at the same time. So, Dean Pruitt clarifies that the readiness is a characteristic of an organization, reflecting the thought of its leaders regarding the conflict with another organization (opponent). The readiness is constituted by two elements. The first is the motivation to put an end to the conflict in the sense that for each party is impossible to achieve a victory. For each part the risks and costs of a victory have an unacceptable dimension. Also, the motivation can result from the pressure of powerful third parties as allies. However, according to Pruitt motivation is not sufficient for the decision of a conflicting part to enter into negotiations. The presence of the second element is necessary, namely the optimism about the negotiation and its results. Optimism means the existence of a belief that the final agreement will satisfy, singularly the goals and aspirations of the conflicting parties without extremely high costs. According to Dean Pruitt the leadership of each conflicting part decides to enter into negotiations after the failure of the unilateral initiatives aiming at the satisfaction of its goals. Optimism is a result of trust building as well as the perception that an acceptable agreement is possible and that the other conflicting part is ready to make the necessary concessions (Pruitt, 2007).

However, Bertram Spector believes that the motivation and willingness to negotiate which configures the conflict ripeness are not sufficient for the decision of the parties towards the start of negotiations. Therefore, Spector argues that the conflicting part decides to enter into negotiations when it has motivation, willingness, and ability to negotiate (Spector, 2002, p. 79). In this context the author introduces the concept of readiness for negotiation as being the combination between the motivation, the willingness, and the ability to negotiate. In this manner Spector concludes that the ability to negotiate and the conflict ripeness are strategically linked. According to him both must be present so that the parties decide to start negotiations (Spector, 2002, p. 80).

Based on the conceptual and theoretical discussion presented above, in the context of this work, conflict ripeness is understood as being the situation characterized by the perception of the mutually hurting stalemate, raising the costs of pursuing a unilateral solution to uncomfortable levels (unacceptable) between conflicting parties, consequently creating motivation, and willingness to negotiate as well as the optimism regarding the results of the negotiation. Motivation and optimism are closely interlinked. Motivation to put an end to the conflict encourages the development of optimism (Pruitt, 2007, p. 1529). Optimism regarding the results of the negotiation helps strengthen the parties' motivation toward the use of negotiation as a mechanism to solve disputes. On the other hand optimism is an important element of ripeness because it contributes to the conflicting parties' decision to start negotiations. Optimism also helps to explain the continued engagement of the conflicting parties in the negotiation process as well as in the implementation of peace agreements. Therefore, parties' optimism regarding favorable results of the peace agreement implementation without high costs contributes not only to its greater involvement in negotiations but also in its support to peace maintenance.

\section{Implementing the General Peace Agreement (GPA): The International Community Participation}

The international community involvement in the GPA implementation process was defined during the peace talks in Rome, Italy, between the Mozambican government led by FRELIMO and RENAMO. In the first protocol signed on 18th October 1991, in Rome, the two conflicting parties have agreed on the principle of setting up a 
committee to supervise and monitor compliance with the GPA. ${ }^{1}$ The committee would be composed of the representatives of the government, RENAMO, the organization of the United Nations (UN) and other organizations or governments. On 13th November of the same year, the representatives of the government and RENAMO signed the second protocol on the criteria and modalities for the establishment and recognition of the political parties. Through this protocol, the two parties reached the understanding according to which the Committee responsible for the supervision and control of the GPA would also be responsible for the analysis and decision on the disputes that might occur in the process of registration of political parties. ${ }^{2}$

On 12 March 1992, the delegations of the government of Mozambique and RENAMO signed Protocol III on the principles of electoral law under which the two parties agreed to invite the United Nations (UN), the Organization of African Unity (OAU), and other organizations, as well as foreign personalities in order to act as observers, in order to guarantee the objectivity of the electoral process. ${ }^{3}$ The reaffirmation of the acceptance of the role of the international community in monitoring and guarantying the implementation of the GPA, in particular, of the cease-fire and the electoral process took place on 7 August 1992, in Rome, Italy, through a joint declaration signed by Joaquim Chissano, President of the Republic of Mozambique and Afonso Dhlakama, President of RENAMO, in the presence of Robert Mugabe, President of Zimbabwe, Gaositwe Chiepe, Minister of Foreign Affairs of Botswana and the mediators, notably, Mario Raffaelli, representative of the Italian Government, Jaime Gonçalves, Archbishop of Beira, Andrea Riccardi, and D. Matteo Zuppi, both from the Sant'Egidio Community. ${ }^{4}$

The Protocol V on the Guarantees signed by the delegations of the Mozambican government and RENAMO, on 4th October in Rome, Italy, reconfirmed the need for the international community intervention in the GPA implementation process. This protocol establishes that shortly after the signing of the GPA, the government would ask for technical and material support from the UN and the OAU. ${ }^{5}$ The Protocol V created the Committee of Supervision and Control (CSC) whose duties are: to ensure the respect of the timetable for the ceasefire and for the holding of elections; to be responsible for the authentic interpretation of the agreements; to resolve any disputes that might arise between the parties; and to guide and coordinate the activities of the subordinated committees. ${ }^{6}$ In accordance with the Protocol V, the CSC would be composed by representatives of the government of Mozambique, RENAMO, UN, OAU, and the countries to be agreed between the signatories to the GPA.

The involvement of the international community in GPA implementation process was supported by the government of Mozambique and RENAMO. Such support resulted from the concern of both parties regarding the

\footnotetext{
1 "Protocolo I dos Princípios Fundamentais, S. Egídio, Roma, 18 de Outubro de 1991". In T. Hansma (Ed.), Acordo Geral de Paz de Moçambique, 1992. Amsterdam: African-European Institute, 1993, p. 8.

2 "Protocolo II dos Critérios e Modalidades para a Formação e Reconhecimento dos Partidos Políticos, S. Egídio, Roma, 13 de Novembro de 1991". In T. Hansma (Ed.), Acordo Geral de Paz de Moçambique, 1992. Amsterdam: African-European Institute, 1993, p. 17.

3 "Protocolo III dos Princípios da Lei Eleitoral, S. Egídio, Roma, 12 de Março de 1992". In T. Hansma (Ed.), Acordo Geral de Paz de Moçambique, 1992. Amsterdam: African-European Institute, 1993, p. 27.

4 "Declaração Conjunta entre Joaquim Chissano, Presidente da República de Moçambique e Afonso Dhlakama, Presidente da RENAMO, Roma, 7 de Agosto de 1992”. In T. Hansma (Ed.), Acordo Geral de Paz de Moçambique, 1992. Amsterdam: African-European Institute, 1993, p. 81.

5 "Protocolo V das Garantias, I, n 2, alínea b), S. Egídio, Roma, 4 de Outubro de 1992". In T. Hansma (Ed.), Acordo Geral de Paz de Moçambique, 1992. Amsterdam: African-European Institute, 1993, p. 49

6 "Protocolo V das Garantias, II, n 1 e 5, S. Egídio, Roma, 4 de Outubro de 1992". In T. Hansma (Ed.), Acordo Geral de Paz de Moçambique, 1992. Amsterdam: African-European Institute, 1993, p. 51.
} 
problem of credible commitment. Given the doubts of both parties on the genuineness of its commitment to peace and, fearing that the signing of the peace agreement and particularly the establishment of a cease-fire could be used by one of the former warring factions against one another, the Mozambican government and RENAMO saw the international community as an instrument to guarantee the respect of the agreement which put an end to the conflict. Therefore, the intervention of the international community, particularly the UN and the OAU, admittedly impartial bodies in relation to the dispute between RENAMO and the Mozambican government provided assurances that none of the parties in dispute would get military and political advantages, unilaterally, from the peace process at the expense of another.

Although the government of Mozambique and RENAMO were favorable to the intervention of the international community in the GPA implementation process, the two parties had different positions in relation to the extent of such intervention. RENAMO was arguing for an intervention of great magnitude of the UN and the western powers in the implementation of the GPA in Mozambique. This position resulted from the fact that, first, RENAMO had a fear that once signed the GPA and reached a cease-fire, the FRELIMO government could use the state power to prosecute, punish, and eliminate the movement led by Afonso Dhlakama, rejecting its place as a relevant political actor. Second, the UN intervention of great magnitude in the supervision and monitoring of the GPA implementation would contribute for the political affirmation of RENAMO internally and internationally, restoring its image vis-a-vis its participation in the national political space, in general, and particularly in the first multiparty elections (MacQueen, 2006, p. 199).

For the Mozambican government, the intervention of the international community was fundamental because it could provide the necessary resources for the implementation of complex tasks and burdensome procedures in the context of GPA such as demobilization and social reintegration of both sides armed forces, repatriation of displaced people and refugees, the preparation of the first multiparty elections, and the reconstruction of social and economic infrastructures destroyed during the war (Notícias, 5 January 1993). Also, the involvement of the UN and the sending of foreign peacekeeping forces were seen by the government led by FRELIMO as the implicit qualification of its sovereignty (MacQueen, 2006, p. 199). The government considered that the intervention of the international community in the GPA implementation process could represent a pressure for a greater engagement of the RENAMO in preserving peace in Mozambique.

However, contrary to the position of RENAMO, the Mozambican government did not want an intervention of great magnitude of the UN in Mozambique so that sovereignty and state power would not be disturbed. According to Dennis Jett, former U.S. Ambassador in Mozambique, after the signing of the GPA FRELIMO's government was shocked to hear about the plans of the UN Secretary General to send around 7,300 Blue helmets to Mozambique at a time in which the Mozambican authorities believed that a United Nations presence in national territory would vary between 100 and 300 military observers not armed (Jett, 2001, p. 68). It is important to emphasize that the Mozambican government was very much in favor of an African solution, namely the intervention of the OAU. FRELIMO's government wanted to avoid at all costs a UN intervention in Mozambique which could be similar to the United Nations Transitional Authority in Cambodia (UNTAC). The UNTAC was established in 1992, being one of the most ambitious peacekeeping operations of the United Nations, assuming the administrative responsibilities in the country (Ratner, 1995, p. 3).

It is important to emphasize that the magnitude of the international community intervention, particularly the United Nations in Mozambique was determined by the immediate needs of the peace process (MacQueen, 2006, p. 199). The fears regarding the possibility of collapse of the peace process in Mozambique in the likeness of the 
Angolan experience led the UN to devote greater attention, human resources, financial and material resources to the UN operation in Mozambique (ONUMOZ) in order to ensure the success of the pacification process in the country (Jett, 2001). ${ }^{7}$

After the signing of the GPA, on 4 October 1992, Joaquim Chissano addressed a letter to the UN Secretary General, Boutros Boutros-Ghali, inviting him to take the appropriate measures in order to ensure the participation of the United Nations in monitoring the implementation of the agreement and provide technical support to the Mozambican government in the preparation and monitoring of the elections (1995, p. 105). ${ }^{8}$ In this context, on 13th October 1992, Boutros Boutros-Ghali has appointed Aldo Ajello as the UN Secretary General Special Representative in Mozambique with the task of coordinating the work of the organization in the implementation of the GPA. Thus, Aldo Ajello and 21 military observers arrived in Mozambique on 15 October 1992.

Aldo Ajello immediately established contacts with Joaquim Chissano and Afonso Dhlakama and favored the holding of regular meetings of consultation and information with the ambassadors of the states represented at the CSC, in particular, the USA, Italy, France, Portugal and the United Kingdom, with the ambassadors of the countries accredited in Maputo, possessing a permanent representation at the UN Security Council and other bilateral donors in Mozambique. Through these meetings all international actors-key were extensively briefed on the Mozambican peace process and the different views among them were coordinated before sending reports to their respective capitals (Manning \& Malbrough, 2010, pp. 155-159). This style of leadership of the Special Representative of the UN Secretary General has proved to be of crucial importance for the success of the peace process in Mozambique.

The increasing cooperation between the Government of Mozambique and RENAMO in the construction of the GPA and above all in the process of its implementation contributed to encourage the engagement of the international community in supporting the pacification process of the country. The goodwill of the former warring parties toward the implementation of the GPA seems to have contributed to the greater mobilization of international support. Member states tend to engage in peace support operations with higher probability of success. In the context of lower probability of success, the states and international intergovernmental organizations tend to avoid the intervention initiatives. Such state attitude results from the need to prevent the damage of its domestic and international reputation which could result from a failed intervention (Aydin, 2010; Jacobsen, 1996).

It was in the context of the perception of a higher probability of success that through the Resolution 797, the UN Security Council adopted, on 16 December 1992, the establishment of the UN operation in Mozambique (ONUMOZ) for which have been mobilized high levels of financial, technical, material, and military resources. In this resolution the UN Security Council stressed the efforts made by the Government of Mozambique and RENAMO to maintain the cease-fire. ${ }^{9}$

\footnotetext{
7 The analysis on the failure of the United Nations Angola Verification Mission (UNAVEM II) and its influence on the United Nations Mission in Mozambique (ONUMOZ) is developed by D. C. Jett, Why Peacekeeping Fails (New York: Palgrave Macmillan, 2001).

8 "Letter Dated 4 October 1992 From the President of the Republic of Mozambique Addressed to the Secretary-General, S/24635, 8 October, 1992". In The United Nations and Mozambique, 1992-1995, With an Introduction by Boutros Boutros-Ghali, Secretary-General of the United Nations. The United Nations, Blue Book Series, Vol. V. New York: Department of Public Information, 1995, p. 105.

9 “Security Council Resolution Establishing ONUMOZ, S/RES/797 (1992), 16 December 1992". In The United Nations and Mozambique, 1992-1995, With an Introduction by Boutros Boutros-Ghali, Secretary-General of the United Nations. The United Nations, Blue Book Series, Vol. V. New York: Department of Public Information, 1995, p. 158.
} 
The intervention of the international community played an important role in strengthening the capacity of the Mozambican State for the implementation of complex tasks in the context of the GPA, namely, demobilization and social reintegration of combatants from the government and RENAMO, the formation of a new unified army, the return of displaced people and refugees of war, the preparation of the first multiparty elections and national reconstruction. Also, the intervention of the international community was seen by the ex-combatants as a credible assurance that the GPA would be respected (Walter, 1999).

\section{Demobilization of Combatants}

The demobilization and social reintegration of the government armed forces and RENAMO's combatants as well as the formation of the unified army were the main elements of the protocol IV part of the GPA, signed on 4th October 1992. In accordance with this protocol, shortly after the signing of the agreement, the Committee of Cease Fire (CCF) would be created, composed by the representatives of the government, RENAMO, the invited countries and the United Nations. The UN would assume the presidency of the Committee. Among other tasks CCF had to implement the demobilization process. According to the terms agreed in the Protocol IV, the demobilization process should be completed in a period of approximately six months from the date of the establishment of the CCF which would be immediately following the signing of the GPA.

However, the period immediately after the signing of GPA was marked by delays in the establishment of the main committees, particularly, CSC and CCF. The delay resulted from the fact that RENAMO continued with their official delegation in Gorongosa, Sofala Province. RENAMO made the establishment of its delegation in Maputo dependent of the creation of conditions and logistical support in Maputo by the Mozambican government. However, it seems that the uncertainties in relation to safety, the fears of possible persecution and doubts about the commitment of the government to fulfill faithfully the GPA were the reasons for fear of RENAMO in establishing itself in Maputo- a region under the FRELIMO's influence. Additionally, behind the delay was the fact that RENAMO faced a lack of cadres in number and with the necessary qualifications to be part of the committees that should be created within the framework of the GPA (Cabaço, 1995, p. 96). Thus RENAMO sought to gain time to meet the conditions for their participation in the implementation phase of GPA for which was not appropriately prepared.

As a result of a coordinated work and pressure from the international community, 35 centers of cantonment out of 49 planned were opened in December 1993. At the end of January 1994, 16,609 combatants were moved to the centers from which 9,895 from the government army and 6,714 from RENAMO. These numbers represented $30 \%$ of the total number of combatants expected in the 35 centers of cantonment. ${ }^{10}$ The process of dismantling the paramilitary armed groups has begun within the same month. In February 1994 the remaining 14 cantonment centers were opened. ${ }^{11}$ In the same month the UN Security Council adopted a resolution authorizing the establishment of the police component of ONUMOZ - a condition presented by RENAMO and agreed with the government in September 1993. The adoption of the police component of the ONUMOZ by the UN Security Council strengthened the security guarantees required by RENAMO. Eventually, this fact contributed to the

\footnotetext{
10 "Report of the Secretary-General on ONUMOZ, S/1994/89". In The United Nations and Mozambique, 1992-1995, With an Introduction by Boutros Boutros-Ghali, Secretary-General of the United Nations. The United Nations, Blue Book Series, Vol. V. New York: Department of Public Information, 1995, p. 217.

11 "Report of the Secretary-General on ONUMOZ, S/1994/511, 28 April 1994". In The United Nations and Mozambique, 1992-1995, With an Introduction by Boutros Boutros-Ghali, Secretary-General of the United Nations. The United Nations, Blue Book Series, Vol. V. New York: Department of Public Information, 1995, p. 233.
} 
beginning of the demobilization process in March 1994.

In mid-April, 12,756 combatants of which 12,195 from the government and 561 from RENAMO were demobilized. ${ }^{12}$ This number reveals the delay and the slowness which continued to mark the demobilization whose end was planned for May of the same year. This slowness reveals that, despite the improvement in confidence, the parties engaged in the demobilization process, however, seeking to avoid the creation of situations of military disadvantage. Due to the delay, in May, the UN Security Council adopted a resolution calling upon the government and RENAMO completion of the cantonment of its forces until 1 June and the demobilization until 15 July. ${ }^{13}$ However, until the beginning of July, the government had only 22,832 combatants demobilized corresponding to $46 \%$ of the expected number and RENAMO demobilized only 5,138, corresponding to $54 \%$ of its total armed forces. ${ }^{14}$ The discrepancies in the numbers of combatants from the government which would be demobilized as a result of errors in the first government projections have led to the resumption of RENAMO's distrust. The movement led by Afonso Dhlakama feared that the government would hide some of their effective military. However, after the negotiations between RENAMO and the government and the completion of the investigations conducted by CSC and CCF, the two parties reached an understanding according to which 64,446 was the number of combatants of the government to be demobilized. ${ }^{15}$ Thus RENAMO's fears were surpassed. Consequently, in October 1994 the two parties completed the demobilization process.

\section{Social Reintegration of Demobilized Soldiers}

At the end of 1993, the model of social reintegration of demobilized soldiers was a subject of many discussions among donors. The director of the United Nations Organization for the Coordination of Humanitarian Assistance (UNOHAC), Bernt Bernander, having worked with the Committee of Reintegration (CORE) has developed a proposal for a reintegration scheme whose duration was three years, including vocational training, the fund for job creation, the distribution of kits, and a credit scheme (Synge, 1997, p. 65). The proposal of Bernander attributed an important role to the Mozambican State in the process of social reintegration of demobilized soldiers through the creation of employment. However a large part of western donors expressed its opposition to the plan of the director of UNOHAC. In accordance with Timothy Born, head of the Program of Demobilization and Demining from the United States Agency for International Development (USAID) and responsible for the relationship between this institution and the UNOHOC between 1992 and 1994:

The donors refused because what Bernander wanted to do would not work. He gave a too much technical and economic role to the Mozambican State. However, we considered that the Mozambican State was not prepared for at that

\footnotetext{
12 "Report of the Secretary-General on UNOMOZ, S/1994/511, 28 April 1994". In The United Nations and Mozambique, 1992-1995, With an Introduction by Boutros Boutros-Ghali, Secretary-General of the United Nations. The United Nations, Blue Book Series, Vol. V. New York: Department of Public Information, 1995, p. 233.

13 "Security Council Resolution Renewing the Mandate of ONUMOZ Until 15 November 1994 and Urging the Mozambican Parties to Allow ONUMOZ Unimpeded Access to the Areas Under Their Control, S/RES/916 (1994), 5 May 1994". In The United Nations and Mozambique, 1992-1995, With an Introduction by Boutros Boutros-Ghali, Secretary-General of the United Nations. The United Nations, Blue Book Series, Vol. V. New York: Department of Public Information, 1995, p. 242.

14 "Report of the Secretary-General on ONUMOZ, S/1994/803, 7 July 1994". In The United Nations and Mozambique, 1992-1995, With an Introduction by Boutros Boutros-Ghali, Secretary-General of the United Nations. The United Nations, Blue Book Series, Vol. V. New York: Department of Public Information, 1995, p. 243.

15 Idem.
} 
time. But we also had, perhaps, political reasons. ${ }^{16}$ (Interview, 2 December 2014)

The opposition to the plan of Bernt Bernander resulted from the fact that the major western donors were arguing for reforms in Mozambique in the direction of economic liberalization and the reduction of State intervention in the economy. Thus, in the perspective of western donors, the State should not intervene in the employment market. In addition, the position of the western donors reflected the fear that the channeling of financial resources to the Mozambican government institutions could provide the diversion caused by corruption which could compromise the success of the demobilization and the entire peace process. It is also important to consider the fear of donors that a program of social reintegration managed by the government could be used for the purposes of political mobilization vis-a-vis the achievement of electoral advantage, therefore, undermining the peace process. Thus, the major western donors, including the United States of America, through USAID advocated for a short-term program aiming to encourage the commitment of ex-combatants with the maintenance of peace. In the context of this short term program, the central role would be played by multilateral organizations and non-governmental organizations (NGOS) (Barnes, 1998, p. 26).

The debate about the model of social and economic reintegration of demobilized lasted until the beginning of the cantonment. ${ }^{17}$ In November 1993, the donors reached an agreement on the establishment of the reintegration scheme support (RSS) proposed by Norway and the Netherlands. The RSS was based on the payment of an allowance for demobilized soldiers during 24 months of which 18 financed by donors and six funded by the Mozambican government (Manning \& Malbrough, 2010, p. 157; Barnes, 1998, p. 26). The subsidy ranged between $15 \$$ for the combatants of the lower echelons and $130 \$$ to the highest echelons, being paid by the subsidiaries of the Banco Popular de Desenvolvimento (BPD) across the country (Alden, 2002, p. 344). The payment of the allowance aimed to ensure that the demobilized soldiers had an income for a relatively long period, avoiding that they were seen as useless by the communities where they would be socially reintegrated. The RSS was established as the main focus of safety issues in the short term - demobilize the interest of ex-combatants in military (McMullin, 2004, p. 626).

The RSS adopted by donors, consisting in the financial and material support to the demobilized soldiers contributed to encourage them to opt for the return to civilian life. The positive response of the demobilized soldiers to financial and materials incentives provided in the context of RSS resulted from the existence of optimism in relation to their reintegration into civilian life, in the social and economic dimensions. The fact that a large part of the combatants of the government and RENAMO have opted for demobilization, rejecting their voluntary incorporation into the new unified army confirms the optimism referred to above.

\section{The Formation of the Single Army}

The GPA established that the formation of the new single army integrating the government and RENAMO forces should start immediately after the cease-fire and also in the context of demobilization. According to the GPA, the government and RENAMO forces would be identified and disarmed. Later on those who voluntarily

\footnotetext{
16 Interview, Timothy Born-Head of Demobilization and Demining Program-United States Agency for International Development (USAID) in Mozambique: 1992-1994, 2 December 2014, Maputo.

17 Interview, Timothy Born-Head of Demobilization and Demining Program-United States Agency for International Development (USAID) in Mozambique: 1992-1994, 26 September 2014, Maputo.
} 
wish to be part of the new single army would be selected for that. However, the successive delays that marked the demobilization led to the late start of the single army formation process.

The coordination of the new army formation process was allocated to Comissão Conjunta para a Formação das Forças Armadas de Defesa de Moçambique (CCFADM). France, the United Kingdom and Portugal joined the CCFADM, assuming responsibility for supporting the process of formation of the new army. The government delegation on CCFADM was led by lieutenant-colonel Tobias Dai and RENAMO's delegation was headed by Mateus Ngonhamo with the same military rank.

In the first quarter of 1993 the Government of Mozambique, RENAMO, the United Kingdom, and Zimbabwe reached an agreement on the training of military instructors of the new national army. The agreement stipulated that in March 1993 the first 100 instructors would be trained in Nyanga, Zimbabwe being 50 from each side (government and RENAMO). However, due to continuous delays, only in August and October 1993 the Mozambican government and RENAMO sent the first 100 elements to Nyanga in Zimbabwe to be trained as military instructors (Notícias, 9 October 1993).

The training played an important role in the standardization of the principles and practices of the new army, as illustrated by the following Mateus Ngonhamo's statement: “the soldiers of the government had its own standard and RENAMO's guerrillas had also its own military practices, principles and behavior. The tactics, strategies, regulations and the organic framework were different between the two forces" (Interview, 4 September 2014). ${ }^{18}$ This argument is corroborated by Lagos Lidimo who explained that:

Within the military training of the new army there was not any political component. The policy was the obedience to the commander in chief. All of us, from RENAMO or government should obey the commander in chief. We did not study politics. ${ }^{19}$ (Interview, 17 September 2014)

Thus, the joint training of forces from both sides was of crucial importance to the creation of unity within the new army.

On 26th October 1993 CCFADM adopted the rules of military discipline of the new army, attributed the name for the army (Armed Forces for Defense of Mozambique-FADM), the structure of the FADM command, and the structure of the joint command of the army (Notícias, 27 October 1993). ${ }^{20}$ These decisions and the approval of the budget of the FADM by CSC during the meeting held on 4 October boosted the process of formation of the new army.

As a result of the decisions referred above and in accordance with the Protocol IV on military issues, the joint command of the FADM was established. This joint command was led by two generals with the same category, namely general Lagos Lidimo, appointed by the government and the general Mateus Ngonhamo appointed by RENAMO. The two generals led together the FADM until the inauguration of the new government resulting from the first multiparty elections in Mozambique. Following the aforementioned protocol, the decisions of Lagos Lidimo and Mateus Ngonhamo were only valid when signed by both, assuming, therefore, the consensus whose construction oblige the parties to develop a culture and spirit of work based on mutual cooperation. The new army began to be built, since early, within a logic and practice of military power sharing

\footnotetext{
18 Interview, Mateus Ngonhamo-Vice-Chief of the Defence Force, from 1995 to 2008, 4 September 2014, Maputo.

19 Interview, Lagos Lidimo - Chief of the Defence Force, from 1995 to 2008, 17 September 2014, Maputo.

20 "Report of the Secretary-General on ONUMOZ, S/26666, 1 November 1993". In The United Nations and Mozambique, 1992-1995, With an Introduction by Boutros Boutros-Ghali, Secretary-General of the United Nations. The United Nations, Blue Book Series, Vol. V. New York: Department of Public Information, 1995, p. 209.
} 
between the government and RENAMO. Therefore, the sharing of military power has helped to reduce the security dilemma between the parties (Rosemary \& Hoddie, 2015, p. 38). Also, the sharing of military power was not only a concrete gesture of genuine commitment to peace but also a credible signal of the conciliatory intention between the former enemies (Hartzel \& Hoddie, 2003).

In accordance with the GPA, the new Mozambican army should be composed of 30,000 men of which 15,000 from the government army and 15,000 from RENAMO's forces. ${ }^{21}$ However, because the number of soldiers interested in joining the new army was too low, the Mozambican government and RENAMO failed to build a new army with 30,000 men. In August 1994 the two sides together had demobilized 60,763 combatants. From this figures 43,297 were from the government and 17,466 from RENAMO. However, in the same period only 7,398 combatants from both sides joined voluntarily the new army of which 3,901 from the government and 3,497 from RENAMO's side. ${ }^{22}$

Given the difficulty of setting an army of 30,000 men, in July 1994, the government and RENAMO reached an agreement according to which the FADM would be formed by the number of soldiers who volunteer for this purpose, thus abandoning the goal previously established in the GPA. ${ }^{23}$ In this context, at the end of 1994 the new unified army was composed of 11,579 men. This number accounted for $39 \%$ of the number originally agreed between the parties within the GPA framework.

The low availability of forces for the new army resulted from several factors. The government forces were clearly less motivated (Vines, 2013, p. 379). According to Lagos Lidimo, senior officer of the governmental forces, guerrilla warfare conducted by RENAMO was very demoralizing. ${ }^{24}$ The precarious conditions in which the soldiers lived, marked by low wages and often paid not on time, poor conditions and logistical support, as well as the fact that many soldiers have been forcibly recruited and remained in the army for very long periods, sometimes exceeding the time laid down by the law of compulsory military service, keeping themselves separated from their families and the desire to experience a life without war, contributed to low interest in joining the new army.

According to Jessica Schafer, less than half of government forces had the opportunity to visit their families during the civil war. The author emphasizes that during the war the forces of the FRELIMO government remained on average eight years without visiting their families (Schafer, 2007, p. 96). Also, the desire to receive financial support and materials provided in the context of RSS influenced the soldier's choice for demobilization, refusing the integration into the new army.

The recruitment often forced into the ranks of the RENAMO, the precarious conditions in which the forces of Dhlakama's movement were living, drought, and famine which worsened their logistic conditions, the desire to return to civilian life, and the interest in having access to financial support and materials arising from the demobilization contributed for the decision to refuse the integration within the new army. It is important to note that almost none of the RENAMO combatant had the opportunity to visit their families during the war and the

\footnotetext{
21 "Protocolo IV das Questões Militares, I, ii, n 1, S. Egídio, Roma, 4 de Outubro de 1992”. In T. Hansma (Ed.), Acordo Geral de Paz de Moçambique, 1992. Amsterdam: African-European Institute, 1993, p. 31.

22 "Further Report of the Secretary-General on ONUMOZ, S/1994/1002, 26 August 1994". In The United Nations and Mozambique, 1992-1995, With an Introduction by Boutros Boutros-Ghali, Secretary-General of the United Nations. The United Nations, Blue Book Series, Vol. V. New York: Department of Public Information, 1995, pp. 252-253.

23 "Final Report of the Secretary-General on ONUMOZ, S/1994/1449, 23 December 1994". In The United Nations and Mozambique, 1992-1995, With an Introduction by Boutros Boutros-Ghali, Secretary-General of the United Nations. The United Nations, Blue Book Series, Vol. V. New York: Department of Public Information, 1995, p. 296.

${ }^{24}$ Interview, Lagos Lidimo-Chief of the Defence Force, from 1995 to 2008, 17 September 2014, Maputo.
} 
desire to do so was huge. Although the factors mentioned above have played an important role, the optimism of the combatants of the government and RENAMO in relation to the results of the demobilization and social reintegration has played a decisive role so that many did not volunteer for the integration in the new army.

Since the signing of GPA and after the first multiparty elections, Renamo and Frelimo shared leadership positions in all branches of the FADM. After the elections Lagos Lidimo, coming from FRELIMO held the position of chief of staff of the army and Mateus Ngonhamo from RENAMO held the post of deputy head. From 1995 and beyond all decisions of the higher hierarchies within the army were taken by consensus. It means that all Lagos Lidimo's decisions in his capacity as chief of staff were taken by consensus with his deputy. This fact was confirmed in interviews conducted by the author to the two military leaders. These facts illustrate the military power sharing between FRELIMO's government and RENAMO.

\section{Territorial Administration, 1992-1994}

The issue of territorial administration was an element of discussion during the negotiations between the government and RENAMO in Rome, Italy, resulting in the establishment of the Protocol V on guarantees, signed in October 1992. Under this Protocol, the government and RENAMO acknowledged that during the period between the entry into force of the ceasefire and the inauguration of the new government, the public administration would continue to obey the law in force in Mozambique. Also the two parties have agreed on the principle according to which the institutions foreseen by the law for the exercise of public administration in areas controlled by RENAMO should make use only of citizens residing there. Additionally those citizens should be RENAMO's members. The relationship between the Ministry of State Administration and the administration in areas controlled by RENAMO should be articulated through the Comissão Nacional Conjunta para a Administração Territorial (CNCAT) composed by representatives of the government and RENAMO. In accordance with the Protocol V, the Committee referred above should enter into force 15 days after the signing of the GPA.

However, the entry into operation of CNCAT was marked by long delay due to the military disputes for territorial control between government forces and RENAMO. In addition the delay resulted from the fact that the movement of Afonso Dhlakama refused to appoint its representatives to the Committee, claiming the lack of housing for accommodation in Maputo.

On 3rd September 1993, Joaquim Chissano and Afonso Dhlakama reached an agreement on the territorial administration under which the government assumed the responsibility to create within the State framework the position of adviser to the provincial governor. In this context, the Mozambican government appointed people presented by RENAMO to be the adviser to the provincial governor. Such advisers had the responsibility to advise the provincial governors in all matters linked directly or indirectly with the reintegration of the regions controlled by RENAMO, including economic and social issues. The adviser received salary from the government.

After long delays, in December 1993, RENAMO provided the names to be appointed as adviser to the provincial governors. Thus in 1994 the government appointed the elements presented by RENAMO to the position of administrators in districts under its control. Either the administrators or the provincial governor advisers exercised their functions until the inauguration of the new government resulting from the first multiparty elections in 1994. The appointment of provincial governor adviser and district administrators represented an example of territorial administration power sharing. This exercise allowed greater cooperation between the 
government and RENAMO. The power sharing in territorial administration, although limited, contributed to crystallize the culture and practice of dialog between the government and RENAMO. Although each of the former conflicting parties sought to satisfy its own interest, the practice of cooperation materialized through dialog has contributed to decrease mutual distrust. Also territorial administration power sharing signaled the commitment of FRELIMO's government to GPA implementation. Therefore, by stimulating cooperation and launching a signal of FRELIMO's government commitment to the GPA implementation, territorial administration power sharing generated and strengthened optimism of the two parties and especially of RENAMO regarding the result of their engagement in the process of maintaining peace in Mozambique.

\section{Building Institutions and Electoral Guarantees}

The creation of the electoral law and the consequent electoral guarantees were some of the main RENAMO and FRELIMO's government concern during the peace negotiations in Rome, Italy. As a result of this concern, in March 1992, the two conflicting parties signed the Protocol III on the principles of electoral law. According to this document, the electoral law should be drawn up by the government in consultation with RENAMO and other political parties existing in Mozambique. ${ }^{25}$ Therefore, although the Mozambican government was recognized, the GPA has limited its ability to legislate (Malan, 1999, p. 173).

In the context of the implementation of the Protocol mentioned above, in March 1993, the Mozambican government completed the preparation of the electoral law draft. However, during a very long period, the Mozambican authorities, RENAMO and the Mozambican unarmed political parties were unable to reach an agreement on such document. The article 16 of the electoral law draft became the main element of dispute.

In accordance with that article, the National Electoral Commission (CNE) should be composed of 21 members. From this number 11 should be from the Mozambican government, seven from RENAMO, and three from unarmed opposition parties. RENAMO and the unarmed opposition parties rejected the proposal for the composition of CNE because they were in a disadvantage position. In response they argued that the government would appoint eight, RENAMO seven, and the remaining parties six members respectively. However, this proposal was rejected by the government.

In October 1993 the UN Secretary General Boutros Boutros-Ghali met Joaquim Chissano and Afonso Dhlakama in Maputo. Boutros-Ghali was able to build an agreement between the two leaders in order to accept the proposal according to which the CNE would be formed by a total of 20 members, of whom 10 appointed by the government, seven by RENAMO, and three representing the remaining political parties. According to the compromise reached between Chissano and Dhlakama with the support of Boutros Ghali, the President of the CNE would be chosen by the 20 CNE members (Notícias, 21 October 1993). ${ }^{26}$ In a situation of lack of consensus among the members of the CNE, they should present a list of five names to the head of state who would chose the President of the electoral institution. It is important to note that the agreement reached on the electoral law, in relation to the CNE composition corresponded to one of the proposals presented by the FRELIMO government. Thus, it can be concluded that FRELIMO government ended dictating the conditions and the direction of the democratization process (Lalá \& Ostheimer, 2003, p. 7).

\footnotetext{
25 "Protocolo III dos Princípios da Lei Eleitoral, S. Egídio, Roma, 12 de Março de 1992". In T. Hansma (Ed.), Acordo Geral de Paz de Moçambique, 1992. Amsterdam: African-European Institute, 1993, p. 19.

26 "Press Briefing by the Secretary-General in Maputo, a Press Release SG/SM/5133, 20 October 1993". In The United Nations and Mozambique, 1992-1995, With an Introduction by Boutros Boutros-Ghali, Secretary-General of the United Nations. The United Nations, Blue Book Series, Vol. V. New York: Department of Public Information, 1995, p. 203.
} 
On 24 November 1993 Joaquim Chissano and Afonso Dhlakama agreed that the government should appoint the general director of the Secretariado Técnico de Administração Eleitoral (STAE). RENAMO and other unarmed opposition parties would appoint two deputy general director of STAE (Notícias, 26 November 1993). According to the agreement the STAE decisions would be taken in a coordinated and consensual manner, being that all documents issued by the electoral body would be signed by the three directors. Additionally Chissano and Dhlakama agreed on the appointment of $37.5 \%$ of the STAE officials by government and other $37.5 \%$ by RENAMO, being that the remaining $25 \%$ would be appointed by the United Nations. Regarding the provincial electoral commissions the two leaders came to the agreement that the government would appoint the president and RENAMO the vice-president. The United Nations would be represented in this board. Thus on 9 December 1993 the Assembly of the Republic adopted in full the draft electoral law, preserving all compromises and consensus reached among the government, RENAMO, and the unarmed opposition parties.

The electoral law approved institutionalized a power sharing situation between FRELIMO's government and RENAMO within STAE and CNE. This power sharing was materialized not only through the sharing of leadership positions but also through the adoption of the principle of consensus in the decision-making process within the electoral institutions. The making and adoption of the electoral law was based on consensus imposed by Protocol III, consequently, removing the government exclusive power of drafting and adopting legislation. In this context it can be concluded that the entire process of building the electoral legislation and institutions clearly represented a practical exercise of political power sharing among the FRELIMO's government, RENAMO, and the unarmed opposition parties. The obligation of consensus has forced the parties to build a relationship based on a greater mutual cooperation.

In February 1994, Brazão Mazula was elected President of CNE. Following a consensus among its members, in April CNE presented a proposal scheduling the first multiparty elections for 27 and 28 October of the same year. ${ }^{27}$ The proposal was approved by the President Joaquim Chissano.

\section{The First Multiparty Elections, 1994: Preserving Peace and Democracy}

\section{The Electoral Campaign}

The electoral campaign has begun on 22 September 1994, lasting until 24 October of the same year. RENAMO and its leader have begun the campaign in Quelimane, Zambézia Province, expressing the optimism regarding the victory as Dhlakama's statement illustrated when he addressed the population present in his rally: “...I am very satisfied. The vote is already there. My victory has already arrived. In Quelimane I have already won..." (18 November 1994) ${ }^{28}$ RENAMO's dominant message was the fight against Marxism-Leninism, to communal villages and guias de marcha. Additionally, RENAMO and its leader promised a religious freedom and the promotion of the Mozambican culture. RENAMO presented itself as the political party which brought democracy in Mozambique.

During the election campaign, Afonso Dhlakama has sought in some occasions to exploit the identities and ethnic differences to obtain electoral advantage. For example, on 30th September, in Gilé district, Zambézia Province, Afonso Dhlakama said:

[...] We recognize the ethnic groups. Here you are lómuès. To say this is tribalism? Not. You have your tradition, we

27 Savana, "Eleições nos dias 27 e 28 de Outubro", 8 April 1994.

${ }^{28}$ Retrospetiva: Campanha Eleitoral de Afonso Dhlakama, 18 November 1994, Televisão de Moçambique (TVM). 
will not say: Ah! This group is not civilized; we will require you to learn this or that. The macuas in this country has never been well respected. But with the government of RENAMO the macuas will be well protected. I want to win the elections, we will change. People should feel that there has been a change. The governor of Zambézia will be zambeziano. It will not be surprising. In public companies there are no zambezianos. This means tribalism? It is important that we recognize a good distribution of power [...] (Cahen, 2004, p. 15)

Continuing the exploitation of ethnicities, on 3th October, in the district of Angoche, Nampula Province, Dhlakama said: "Now the time has come for you macuas to enjoy your freedom which FRELIMO has never considered", stressing that FRELIMO in power despised the macua culture (Notícias, 4 October 1994a). Dhlakama reiterated that if he wins the elections the governor of Nampula Province and district administrators would be macuas of origin in order to prevent the appointment of people belonging to other ethnic groups (Cahen, 2004, pp. 32-33).

In Mutarara district, in Tete Province, Afonso Dhlakama accused Chissano of having ordered the death of thousands of children with the complicity of the Zimbabwean air force, highlighting that one day the sena people would ask for justice. Clearly, Dhlakama was trying to exploit the ethnicities and to respond to the accusations of FRELIMO and its presidential candidate according to which RENAMO was responsible for deaths, misery, and destruction of the country. It is in this context that in Manica Province Dhakama promised to provide the evidence that FRELIMO killed many people during the war.

In Cabo Delgado there was a rumor according to which Dhlakama said that makonde people had its origins in Angola and because of that if he wins the elections he will send this ethnic group to that country. During his campaign in Cabo Delgado, Dhlakama abandoned the ethnic based discourse calling himself as nationalist who is working for national unity. ${ }^{29}$ While in Zambezia, Nampula, and Tete, the leader of RENAMO tried to manipulate ethnic differences, in northern (Cabo Delgado and Niassa provinces) and southern side of the country Dhlakama has distanced himself from the ethnic discourse. In these regions Dhlakama presented a discourse seeking for national agglutination. It should be noted here that Dhlakama has refuted the intention to expel the changana people from the southern part of Mozambique to South Africa, stating that he was misunderstood because he was only responding to the provocations of FRELIMO's presidential candidate. ${ }^{30}$

Although there has been a considerable appeal to the ethnic identities, the electoral campaign cannot be described as having been dominated by such plead. The arguments and appeals to ethnic identities were marginally used by RENAMO and other political competitors (Manning, 2002, p. 148). During the electoral campaign, RENAMO and other political parties did not use systematically the ethnic appeals. ${ }^{31}$ The times in which such appeals took place were made in a dispersed manner, unsystematically and contradictorily. While they called for ethnicity they also appealed for national unity. This fact may have prevented the activation of ethnic sentiment.

While electoral campaign was taking place, RENAMO and its leader became impressed with the high popular participation in rallies. Consequently, Afonso Dhlakama and RENAMO began to see themselves as winners in advance. They stated that only an electoral fraud would impede their victory.

FRELIMO and its candidate performed the electoral campaign confident in victory as evidenced by the

\footnotetext{
${ }^{29}$ Retrospetiva: Campanha Eleitoral de Afonso Dhlakama, 18 November 1994, Televisão de Moçambique (TVM).

30 Idem.

31 According to C. Manning, The Politics of Peace in Mozambique: Post-Conflict Democratization, 1992-2000 (London: Praeger, 2002), p. 148, RENAMO was the party that did more appeals to ethnic identities during the electoral campaign for the first multiparty elections.
} 
repeated rejection of the proposal for a prior understanding for the establishment of a Government of National Unity (GNU). During the campaign, FRELIMO has presented itself as the party of national unity based on its experience of struggle for independence. FRELIMO blamed RENAMO for the deaths, destruction of economic and social infrastructure of the country and for misery affecting a large part of the population as evidenced by the following Chissano's statement during a rally in Quelimane: "RENAMO attacked the population and destroyed shops... we all know the problems and he (Afonso Dhlakama) also knows the problems and difficulties of our people" (Notícias, 4 October 1994b).

It is important to note that while RENAMO feared the occurrence of electoral fraud engendered by the FRELIMO's government, the party in power feared a possible result manipulation by ONUMOZ in favor of Dhlakama's political party. However, in spite of the above-mentioned rumors, FRELIMO was confident and optimistic regarding the electoral results as illustrated by the following declaration of Mariano Matsinha, head of FRELIMO's Electoral Office on 28th September 1994: "We believe in a victory between 60\% and 66\%" (Fauvet \& Mosse, 2004, p. 390). RENAMO was also optimistic regarding the election results, however less confident in victory. The following statement of Vicente Ululu, General Secretary of RENAMO evidenced this fact: "If we win we will form a government. We need people who are prepared to do this. Even if we lose we hope that we will get a very good representation in Parliament" (Notícias, 27 October 1994).

\section{RENAMO's Electoral Boycott: From Fears of War to the Proclamation and Acceptance of Electoral Results}

Two days before the start of the voting, the leaders of the Front Line States, notably South Africa, Angola, Botswana, Mozambique, Namibia, Tanzania, Zambia, and Zimbabwe met in Harare in a summit in order to discuss the developments related to the democratization process in Mozambique with particular focus on the first multiparty elections. Joaquim Chissano attended the meeting on behalf of the Mozambican State where he presented detailed information about the preparation for the elections. Although Dhlakama was invited to Harare by Robert Mugabe, President of Zimbabwe, RENAMO's leader did not participate in that summit.

Afonso Dhalakama received the information contained in the final communiqué resulting from the summit, according to which:

[...] The summit considers that there are conditions for the holding of free and fair elections. The summit urges the parties to respect the election results once declared free and fair, and reaffirms the commitment of the southern African states to accept the decision of the Mozambican people in elections. The summit expresses its firm commitment to support the government which result from elections and to exploit the resources of the region for the consolidation of the democratic order, peace, stability and prosperity of the people of Mozambique. The summit decided to continue to monitor the situation in Mozambique and is ready to undertake the appropriate actions in a timely manner if the situation requires $[\ldots]^{32}$ (25 October, 1994)

Afonso Dhlakama saw the final communiqué of the summit as a threat to RENAMO, obliging it to accept any electoral result favoring FRELIMO and Chissano. Thus the final communiqué strengthened RENAMO's uncertainty and suspicions regarding the elections as evidenced by the following Raúl Domingos statement:

[...] We did not participate in the meeting. After all they called us to threaten as who says we met and if you do not accept the results the Front Line States will be on the side of the FRELIMO to fight. Then, for RENAMO that attitude was an indicator that the fraud was already prepared and the winner would be FRELIMO, and RENAMO was being called

\footnotetext{
${ }^{32}$ Final Communiqué of the Summit Meeting of the Front Line States Held in Harare, Zimbabwe, Tuesday, 25 October, 1994.
} 
attention to accept the result $[\ldots]^{33}$ (Interview, 29 August 2014)

Consequently, on 27th October, Afonso Dhlakama announced RENAMO's withdrawal from the electoral race, adding that he would not recognize the electoral results. . However, Dhlakama ensured that he would not return to war. The fear of a defeat that could put RENAMO in a condition of political marginality in post-election period and the need to build an agreement aiming at the establishment of GNU contributed to Dhlakama's decision.

The decision to abandon the electoral process proved catastrophic, putting RENAMO and its leader under enormous regional and international pressure. The decision taken by Dhlakama greatly harmed the credibility of RENAMO. From different countries and international organizations, including UN Security Council, RENAMO received messages criticizing its decision and demanding that the party should reconsider it.

As a result of international pressure and after receiving the guarantees of the international community according to which it would investigate the allegations of fraud, Dhlakama decided to return to the electoral race. In turn, the CNE decided to extend the voting process until 29th October. The decision to return to the electoral race was preceded by the signing of a joint declaration by the ambassadors of the countries represented in the CSC, Aldo Ajello and by RENAMO.

On 31 October, Afonso Dhlakama met Brazão Mazula, President of the CNE and promised that he was willing to accept any outcome of the elections even if it was unfavorable to himself and for his party. In addition he argued that he has not struggled for power but for democracy in Mozambique. This statement was in the context of Dhlakama's efforts to get rid of stains resulting from the electoral boycott and to rehabilitate his public image.

However when the first electoral results began to appear giving advantage to FRELIMO, especially in the southern region, RENAMO's fears became activated. In this context Raul Domingos said that Renamo would not accept the electoral result as it appeared at that moment. In RENAMO's view that electoral result was fraudulent and unacceptable (Notícias, 8 November 1994).

However, as time passed, and particularly at the end of the first half of November, the electoral results have begun to place RENAMO in second position well balanced with FRELIMO. Sure that FRELIMO had reached the victory and that RENAMO managed to get positive and encouraging results, Afonso Dhlakama began to abandon the discourse based on the rejection of electoral results.

In this context, through a telephone call, Afonso Dhlakama assured the UN Secretary General that he would accept the electoral results despite the irregularities. He also showed his readiness to cooperate with the post-electoral government of Mozambique. This assurance was also given to Aldo Ajello in Maputo.

On 19 November, the President of the CNE publicly announced the official results of the first multiparty elections (presidential and legislative) in Mozambique. According to the electoral results, Joaquim Chissano was elected President of the Republic with 2,633,740 votes corresponding to 53.30\% and Afonso Dhlakama conquered the second position with $1,666,965$ votes, corresponding to $33.73 \%$. In the legislative elections, FRELIMO won 2,115,793 votes, corresponding to 44.33\%, RENAMO received 1,803,506 votes corresponding to $37.78 \%$ and the Democratic Union reached 245,793 votes, corresponding to 5.15\% (Mazula, 1998, p. 33). RENAMO won the largest number of votes in Central and Northern provinces of the country, namely Sofala,

\footnotetext{
33 Interview, Raúl Domingos-Head of RENAMO's Delegation during the Peace Talks in Rome, Italy, from 1991 to 1992,29 August 2014, Maputo.
} 
Manica, Tete, Zambezia, and Nampula. FRELIMO won the largest votes in Southern and northern provinces, specifically, Maputo city, Maputo province, Gaza, Inhambane, Niassa, and Cabo Delgado. However, the votes were distributed in almost all provinces with the exception of Gaza province where RENAMO was unable to elect any member of parliament.

Afonso Dhlakama said that his party accepted the electoral results because the first multiparty elections and the subsequent announcement of its results was a victory for RENAMO and Mozambican people. This statement reveals RENAMO's satisfaction with the electoral results achieved. Moreover this satisfaction was also expressed by Afonso Dhlakama to Brazão Mazula, President of CNE to whom he said: "We came from the bush. We were not expecting so many votes. We thought that people would not vote on us... More than a Presidency of the Republic the most important was the Parliament" (Interview, 28 August 2014). ${ }^{34}$

Joaquim Chissano accepted the electoral results and stated that: "the nation must ensure a decent status to the second presidential candidate most voted. It is a necessary innovation to be introduced in the customs and policy practices within a country, especially when it emerges from a conflict" (Notícias, 21 November 1994). With this gesture Chissano sought to avoid the political marginalization of Afonso Dhlakama, ensuring his integration. Joaquim Chissano was seeking to ensure Dhlakama's engagement in democratic process and pacification of the country.

\section{Conclusion}

The GPA implementation was often characterized by mistrust between the government led by FRELIMO and RENAMO, revealing the existence of the problem of credible commitment between the two parties. Suspicions have contributed to the delay in the implementation of the main tasks laid down in the GPA, namely, the demobilization and social reintegration of combatants from both sides of the conflict, the formation of a new unified army, the approval of the electoral law, and the completion of the first multiparty elections in the country. However, the intervention of the international community in the GPA implementation has helped to provide the financial, material, and technical resources for the Mozambican State without which it could not respond to the demands raised by the complex tasks established within the agreement. In this way, the international community has contributed to the strengthening of the capacity of the Mozambican State deeply undermined as a result of the war. Also, the intervention of the international community through ONUMOZ provided guarantees to ex-combatants that the GPA would be complied by both parties. Therefore international community contributed to decrease the problem of credible commitment. In this way, the international community has contributed to generate optimism of the two former conflicting parties regarding the result of GPA implementation.

The military power sharing, territorial and administrative power sharing as well as the political power sharing (power to legislate) between the former warring parties and unarmed opposition parties, particularly in the process of drafting and adopting the electoral law has contributed to reduce the problem of credible commitment. Additionally the military, political, territorial, and administrative power sharing increased mutual cooperation, strengthening trust, and in this way, generating optimism of the parties regarding the results of their engagement in the GPA implementation process and democratization.

In this context, the Mozambican case confirms the theoretical approaches according to which the establishment of peace agreements containing provisions for military, territorial and political power sharing tends

34 Interview, Brazão Mazula-President of the National Electoral Committee (CNE), from 1993 to 1995, 28 August 2014, Maputo. 
to promote more durable peace in post-conflict societies experiencing simultaneously a democratic transition.

The preparation of the electoral law has configured itself as an eminently political process. The sharing of power among FRELIMO's government, RENAMO and the unarmed opposition parties in the process of drafting the law contributed to cementing the collaboration and cooperation between the actors mentioned above and for the establishment of institutions and electoral guarantees reliable and stable.

It is important to note that FRELIMO's government was confident and optimistic regarding the electoral results. Therefore FRELIMO's government rejected continuously the possibility of GNU. RENAMO was optimistic regarding the electoral results, however, less confident in victory. In fact, it is important to emphasize that during peace negotiations in Rome, RENAMO argued for the adoption of political and electoral system based on proportional representation. This position resulted from RENAMO's uncertainty regarding the electoral victory. It also resulted from RENAMO's optimism regarding its representation within the Parliament.

Finally, the most crucial element for the maintenance of peace and democracy was the nature of the electoral results. The electoral results have generated a situation of almost balance of power within the Parliament between the former belligerents. RENAMO elected 112 members of Parliament, UD nine members of Parliament and the FRELIMO 126 members of Parliament. With these results FRELIMO remained with power. The same electoral results conferred a place and political legitimacy to RENAMO in Mozambique. Faced with these electoral results, the costs of return to violence either to RENAMO either for the government appeared to be much higher than the estimates costs of maintaining peace and democracy.

For the government of FRELIMO and RENAMO, any military action in the post-election period was difficult for the following reasons: First it was necessary to find a political argument (objective and subjective) reasonable to justify military action at domestic, regional, and international levels. Apparently, none of the parties had such political argument. Second, the two parties had lost control over most of its military effective. This fact revealed that political leaders would have difficulties in mobilizing the forces for war.

It is important to emphasize that the outcome of the first elections contributes to the generation of the optimism of the two former conflicting parties regarding the next elections. This optimism has encouraged the two parties to support the maintenance of peace and democracy. Although RENAMO has not won the elections, its optimism regarding the next election influenced its decision to support peace and democracy. Due to the electoral results achieved, RENAMO believed that it could achieve political power via democratic means in the next elections. Also, FRELIMO victory has crystallized optimism regarding the results in the subsequent elections. This optimism influenced FRELIMO decision to support peace and democracy.

\section{References}

Achankeng I, F. (2012). Mutual hurting stalemates, ripe moments and third-party intervention: Implications for the "Southern Cameroons restoration of statehood conflict". The Round Table: The Commonwealth Journal of International Affairs, 101(1), 53-69.

Alden, C. (2002). Making old soldiers fade away: Lessons from reintegration of demobilized soldiers in Mozambique. Security Dialog, 33(3), 341-356.

Aydin, A. (2010). Where do states go? Strategy in civil war intervention. Conflict Management and Peace Science, 27(1), 47-66.

Barnes, S. (1998). Humanitarian aid coordination during war and peace in Mozambique: 1985-1995. Studies on Emergency and Disaster Relief, Report No. 7. Uppsala: Nordiska Afrikainstitutet.

Cabaço, J. L. (1995). A longa estrada da democracia moçambicana (The long road of Mozambican democracy). In B. Mazula (Coord.), Moçambique: Eleições, Democracia e Desenvolvimento (Mozambique: Elections, democracy and development) (pp. 79-114). Maputo: Patrocínio Embaixada do Reino dos Países Baixos. 
Cahen, M. (2004). Os Outros: Um Historiador em Moçambique, 1994 (The Others: A Historian in Mozambique, 1994). Basel: P. Schlettwein Publishing.

Fauvet, P., \& Mosse, M. (2004). É Proibido Pôr Algemas nas Palavras: Uma Biografia de Carlos Cardoso (It is Prohibited to Put Handcuff on Words: A Biography of Carlos Cardoso). Lisboa: Editorial Caminho.

Forde, S. (2004). Thucydides on ripeness and conflict resolution. International Studies Quarterly, 48(1), 177-195.

Greig, J. M. (2001). Moments of opportunity: Recognizing conditions of ripeness for international mediation between enduring rivals. The Journal of Conflict Resolution, 45(6), 691-718.

Hartzel, C. A., \& Hoddie, M. (2003). Civil war settlements and the implementation of military power-sharing arrangements. Journal of Peace Research, 40(3), 303-320.

Honwana, J. B. (1995). The United Nations and Mozambique: A sustainable peace? Lisboa: Instituto de Estudos Estratégicos e Internacionais.

Jacobsen, P. V. (1996). National interest, humanitarianism or CNN: What triggers UN peace enforcement after the Cold War? Journal of Peace Research, 33, 205-215.

Jett, D. C. (2001). Why peacekeeping fails. New York: Palgrave Macmillan.

Kleiboer, M. (1994). Ripeness of conflict: A fruitful acoustics? Journal of Peace Research, 31(1), 109-116.

Lalá, A., \& Ostheimer, A. E. (2003). Como Limpar as Nódoas do Processo Democrático? Os Desafios da Transição e Democratização em Moçambique, 1990-2003 (How to Clean the Taints of Democratic Process? The Challenges of Transition and Democratization in Mozambique, 1990-2003). Maputo: Konrad-Adenauer-Stiftung.

MacQueen, N. (2006). Peacekeeping and the international system. London and New York: Routledge.

Malan, M. (1999). Peacebuilding in Southern Africa: Police reform in Mozambique and South Africa. International Peacekeeping, 6(4), 171-190.

Manning, C. (2002). The politics of peace in Mozambique: Post-conflict democratization, 1992-2000. London: Praeger.

Manning, C., \& Malbrough, M. (2010). Bilateral donors and aid conditionality in post-conflict peacebuilding: The case of Mozambique. Journal of Modern African Studies, 48(1), 143-169.

Mazula, B. (1998). Moçambique: Dados Estatísticos do Processo Eleitoral 1994 (Mozambique: Statistical Data of the Electoral Process, 1994). Maputo: STAE.

McMullin, J. (2004). Reintegration of combatants: Were the right lessons learned in Mozambique? International Peacekeeping, 11(4), 625-643.

Notícias. (21 November 1994). Chissano promete estatuto condigno ao segundo mais votado.

Notícias. (21 October 1993). Após encontro trilateral com Chissano e Dhlakama, Ghali quebra impasses e impulsiona processo de paz: Governo e a RENAMO acordam composição da CNE e desmobilização das tropas e milícias.

Notícias. (26 November 1993). Desbloqueado impasse na elaboração da lei eleitoral: Chissano e Dhlakama avistaram-se em Maputo.

Notícias. (27 October 1993). Aprovada estrutura do EMG do futuro exército único: CCFADM esteve reunida ontem no clube military.

Notícias. (27 October 1994). Cabo Delgado, Ululu garante que a RENAMO vai aceitar os resultados.

Notícias. (4 October 1994a). Chegou o momento de gozarem a liberdade, diz Dhlakama em Nampula.

Notícias. (4 October 1994b). Em Quelimane, Chissano cantou, dançou e pediu votos... chegou a Maputo e foi acolhido em festa.

Notícias. (5 January 1993). Aplicação do acordo exigirá muitos recursos: Presidente da República falando ontem ao corpo diplomático acreditado em Maputo.

Notícias. (8 November 1994). Partido de Dhlakama poderá não aceitar os resultados: Diz Raúl Domingos à Voz da América.

Notícias. (9 October 1993). Segundo contingente militar da RENAMO chegou ontem a Nyanga: Ajello confirma a vinda de peritos da ONU para trabalhar com a PRM.

Preston, M. (2004). Stalemate and the termination of civil war: Rhodesia reassessed. Journal of Peace Research, 41(1), 65-83.

Pruitt, D. G. (2005). Whither ripeness theory? Institute for Conflict Analysis and Resolution, George Mason University, Working Paper No. 25.

Pruitt, D. G. (2007). Readiness theory and the Northern Ireland conflict. American Behavioral Scientist, 50(11), $1520-1541$.

Ratner, S. R. (1995). Building peace in lands of conflict after the Cold War: The new UN peacekeeping. New York: St. Martin's Press.

Rosemary, C. A., \& Hoddie, M. (2007). Crafting peace: Power-sharing institutions and the negotiated settlement of civil wars. Pennsylvania: Pennsylvania State University Press. 
Rosemary, C. A., \& Hoddie, M. (2015). The art of the possible: Power sharing and post-civil war democracy. World Politics, 67(1), 37-71.

Rothchild, D. (1997). Managing ethnic conflict in Africa: Pressures and incentives for cooperation. Washington, D.C.: Brookings Institution Press.

Schafer, J. (2007). Soldiers at peace: Veterans and society after the civil war in Mozambique. New York: Palgrave Macmillan.

Schrodt, P. A., Yilmaz, Ö., \& Gerner, D. J. (2003). Evaluating ripeness and hurting stalemate in mediated international conflicts: An event date study of the Middle East, Balkans, and West Africa. Paper prepared for delivery at The Annual Meeting of the International Studies Association. Portland, Oregon, USA.

Sousa, R. (2012). Mudanças multidimensionais em Angola aquando dos acordos de paz de Gbadolite de 1989. In Augusto Nascimento and Carlos Coutinho Rodrigues (coord.), A Prevenção e a Resolução de Conflitos em África (pp.159-190). Lisboa: Instituto da Defesa Nacional.

Spector, B. I. (2002). Negotiation readiness in the development context: Adding capacity to ripeness. In H.-W. Jeong (Ed.), Approaches to peacebuilding (pp. 80-100). New York: Palgrave Macmillan.

Synge, R. (1997). Mozambique: UN peacekeeping in action, 1992-94. Washington D.C.: United States Institute of Peace Press.

Thomashausen, A. (25-26 July 2001). Mozambique: A case study. Paper presented at The Conference on Politics of Identity and Exclusion in Africa: From Violent Confrontation to Peaceful Cooperation. University of Pretoria.

Vieira, S. (2010). Participei, Por Isso Testemunho (I Participated, because of that I testify). Maputo: Ndjira.

Vines, A. (2013). RENAMO's rise and decline: The politics of reintegration in Mozambique. International Peacekeeping, 20(3), 375-393.

Walter, B. (1999). Designing transitions from civil war: Demobilization, democratization and commitments to peace. International Security, 24(1), 127-155.

Weinstein, J., \& Francisco, L. (2005). The civil war in Mozambique: The balance between internal and external influences. In P. Collier and N. Sambanis (Eds.), Understanding civil war: Evidence and analysis (pp. 157-192). Washington DC: The World Bank.

Yusuf, M., \& Najam, A. (2009). Kashmir: Ripe for resolution? Third World Quarterly, 30(8), 1503-1528.

Zartman, I. W. (2000). Ripeness: The hurting stalemate and beyond. In P. C. Stern and D. Druckman (Eds.), International conflict resolution after the Cold War (pp. 225-250). Washington, D.C.: National Academy Press.

Zartman, I. W. (2001). The timing of peace initiatives: Hurting stalemates and ripe moments. The Global Review of Ethnopolitics, $1(1), 8-18$. 